\title{
SENSITIVITY OF AMPLICOR MTB ON DIRECT DETECTION OF MYCOBACTERIUM TUBERCULOSIS IN SMEAR-NEGATIVE SPECIMENS FROM OUTPATIENTS IN RIO DE JANEIRO
}

\author{
Luciano dos Anjos Filho'; Walter M.R. Oelemann²; Clara E.N. Barreto³; Afranio Lineu Kritski'; \\ Leila de Souza Fonseca ${ }^{2 *}$
}

\begin{abstract}
${ }^{1}$ Hospital Universitário Clementino Fraga Filho, Universidade Federal do Rio de Janeiro, Rio de Janeiro, RJ, Brasil. ${ }^{2}$ Instituto de Microbiologia, Centro de Ciências da Saúde, Universidade Federal do Rio de Janeiro, Rio de Janeiro, RJ, Brasil.

${ }^{3}$ Laboratório Noel Nutels, Secretaria Estadual de Saúde do Rio de Janeiro, Rio de Janeiro, RJ, Brasil.
\end{abstract}

Submitted: August 02, 2001; Returned to authors for corrections: March 04, 2002; Approved: May 13, 2002

\section{SHORT COMMUNICATION}

\begin{abstract}
We evaluated the performance of the AMPLICOR MTB assay for detection of M. tuberculosis in clinical specimens obtained from 98 smear-negative tuberculous patients (43 with positive and 55 with negative culture results). The sensitivity of the AMPLICOR MTB was 44.9\% (44/98) and that of culture was $43.8 \%$ (43/ 98). No significant difference was observed between the results obtained by AMPLICOR MTB and by culture. We conclude that amplification assays could be used for testing smear-negative specimens because a rapid diagnosis will benefit those patients.
\end{abstract}

Key words: tuberculosis, AMPLICOR MTB, smear-negative specimens.

Laboratory diagnosis of tuberculosis (TB) currently depends on acid-fast staining and culture of clinical specimens. Microscopic examination of acid-fast smears is not very sensitive, and culture is very specific but usually requires two to three weeks of incubation. Over the last five years several studies evaluated commercial amplification kits designed to directly detect Mycobacterium tuberculosis DNA and RNA in clinical specimens. The amplification techniques had a strong impact on the speed of the TB diagnosis. However, studies carried out in developed countries have demonstrated similar sensitivities for the new methods and conventional culture $(4,8,9)$. So far, no data from primary health care centers were obtained in countries with high incidence of TB. TB is endemic in the city of Rio de Janeiro, Brazil, with an annual incidence rate of 160/100,000 inhabitants (1).

In the present study, we evaluated the performance of the AMPLICOR MTB for direct detection of M. tuberculosis DNA in smear-negative specimens obtained from patients from a TB endemic area who were submitted to specific treatment.
The present study enrolled 98 patients randomly selected from those with smear-negative specimens attending to 18 primary health care centers in the city of Rio de Janeiro during the period from August to December 1996. All patients were suspected of having TB due to the presence of symptoms, but were smear-negative. TB diagnosis was based on clinical, epidemiological and radiological criteria. Sputum was collected from 86 patients with pulmonary tuberculosis, and lymph node, biopsy, pleural fluid and urine specimens were collected from the remaining 12 patients with extra-pulmonary tuberculosis. Socio-demographic data including information on previous TB treatment were obtained by interview.

All samples were collected before the patients started specific therapy for TB and were sent to the Noel Nutels Laboratory. Acid-fast staining was performed by the Ziehl-Neelsen method (6). Contaminated samples were processed by the $\mathrm{NaOH}-\mathrm{N}$-acetylL-cysteine method and $0.1 \mathrm{ml}$ of the sediment was cultured in two Loewenstein-Jensen tubes. M. tuberculosis identification was carried out by standard biochemical and enzymatic tests (6). * Corresponding author. Mailing address: Instituto de Microbiologia, UFRJ, Centro de Ciências da Saúde, Bloco I, Ilha do Fundão. 21941-590, Rio de
Janeiro, RJ, Brasil. Phone: (+5521) 2260-4193, Fax (+5521) 2560-8344. E-mail: 1sfonseca@micro.ufrj.br 
The sediment from processed clinical specimens was tested with the AMPLICOR M. tuberculosis Test (AMPLICOR MTB Roche Diagnostic Systems, NJ, USA) following the instructions of the manufacturer. All samples which gave discrepant results were from patients considered positive for tuberculosis based on the patient's history, signs and symptoms, chest radiography, histology, tuberculin test, and response to empirical tuberculosis treatment. Therefore, samples positive by culture, but negative by PCR were re-tested and checked for the presence of amplification inhibitors.

Data analysis and significance tests by Yates and two-tailed Fisher's exact test were performed using the EpiInfo program version 5.

From 98 smear-negative patients, 43 (43.9\%) were positive by culture for $M$. tuberculosis and 55 (56.1\%) were negative. Of the 43 culture-positive samples, 34 were also positive by AMPLICOR MTB. Considering the culture as gold standard the sensitivity of the AMPLICOR MTB was found to be $79 \%$.

Table 1 gives a detailed analysis of the specimens from 9 patients who were positive by culture and negative by AMPLICOR MTB. All specimens but one were weakly positive by culture ( $\leq 100 \mathrm{CFU} / \mathrm{ml})$, ranging from 0.1 to $30 \mathrm{CFU} / \mathrm{ml}$. Six specimens were found to contain PCR inhibitors. One specimen could not be tested due to insufficient material, and two were negative for PCR inhibitors.

Ten patients with clinical manifestations of TB were culturenegative but PCR-positive. Since our population consisted of patients considered infected by either clinical criteria alone (55 patients with culture-negative samples) or both, clinical and bacteriological criteria (43 patients with culture-positive samples), we decided to define an adjusted gold standard, which included the follow-up of clinical, radiological and bacteriological findings and treatment data. Using this

Table 1. Analysis of the specimens from 9 patients culture positive for M. tuberculosis and negative by Amplicor MTB.

\begin{tabular}{cll}
\hline $\begin{array}{c}\text { Patient } \\
\text { number }\end{array}$ & \multicolumn{1}{c}{ Culture } & \multicolumn{1}{c}{ Comments } \\
\hline 01 & ${\text { Positive }+^{\mathrm{a}}}^{\mathrm{a}}$ & Positive for PCR inhibitors \\
03 & 3 colonies & Positive for PCR inhibitors \\
04 & Positive + & Positive for PCR inhibitors \\
11 & 2 colonies & Positive for PCR inhibitors \\
15 & 1 colony & Positive for PCR inhibitors \\
20 & 18 colonies & Positive for PCR inhibitors \\
21 & Positive + & Negative for PCR inhibitors \\
27 & Positive $++^{\mathrm{b}}$ & Insufficient material for PCR \\
39 & Positive + & Negative for PCR inhibitors \\
\hline
\end{tabular}

${ }^{\mathrm{a}}$ Positive +20 to 100 colonies; ${ }^{\mathrm{b}}$ Positive ++100 to 300 colonies. adjusted gold standard, the number of confirmed tuberculosis cases changed from 43 (culture positive) to 98 patients (all patients). The overall sensitivity of the AMPLICOR MTB was $44.9 \%$ (44 out of 98), and, therefore, not significantly different from the sensitivity of $43.8 \%$ (43 out of 98) obtained for culture.

Rapid diagnosis and prompt initiation of therapy are critical for TB control. In acid-fast smear-positive patients, antituberculosis therapy normally begins after the smear results are reported. Therefore, nucleic acid amplification test would be most beneficial in smear-negative patients. For these patients, nucleic acid amplification can confirm a TB diagnosis much earlier than culture. Previous criticisms regarding the performance of nucleic acid amplification test on smear-negative specimens included their low sensitivity (approximately 50\%) and occasional false-positive results (2). Our study differs from others because it enrolled only smear-negative TB patients. More than 50\% (55/98) of these were also culturenegative. When our PCR results were compared only with culture as gold standard in TB diagnosis, the sensitivity of the AMPLICOR MTB was 79\%. (34/43). Negative results obtained by amplification assays for culture-positive specimens may be explained by the presence of inhibitors of enzymatic amplification and/or by small number of mycobacteria, unequally distributed in the test suspension $(3,7)$. Nonviable M. tuberculosis could be one reason for culture - negative/PCR positive results. Decontamination during sample processing could reduce the viability of mycobacteria in paucibacillary samples below the sensitivity threshold of culture diagnosis. Devallois et al. (3) reported AMPLICOR MTB positive results on specimens containing 2 to $10 \mathrm{CFU}$. However, in our study, four specimens containing 1 to $18 \mathrm{CFU}$ were culture-positive but PCR-negative and were found to contain endogenous inhibitors. Inhibitor presence was reported to occur in 5 to $13 \%$ of the specimens. $(5,8,10)$. In our study $5 \%$ of the specimens contained inhibitors that were responsible for 6 out of 9 falsenegative results.

Data obtained in our study and by others also indicate that, at this moment, PCR cannot replace mycobacterial culture. Considering all patients (culture-positive and negative specimens), the sensitivity of the PCR assay was $44.9 \%$, similar to that obtained in conventional culture (43.8\%). On the other hand, no reliable rapid detection system for anti-tuberculosis drug resistance is available, and culture methods are still required for susceptibility testing. Therefore, PCR is a supplementary test that requires additional resources and recommendations for its appropriate use. Studies carried out regarding the role of PCR in diagnosis as well as tuberculosis patient management should include optimal use of PCR in testing acid-fast smear-negative specimens, because a rapid diagnosis clearly will benefit certain patients whose sputum smears are negative. 


\section{ACKNOWLEDMENTS}

We thank the Laboratório Bronstein and Dr. Mário Bronstein for providing the equipment for Amplicor MTB tests.

This publication was supported by grants from $\mathrm{CNPq}, \mathrm{FUJB}^{\circ}$ 9070-1 and FAPERJ (Brazil), and by a subcontract from the Johns Hopkins University with funds provided by grant $n^{\circ} 1$ U19A I4543201 from NIH. Its contests are solely the responsibility of the authors and do not necessarily represent the official views of NIH.

\section{RESUMO}

\section{Sensibilidade do kit Amplicor MRB na detecção direta de Mycobacterium tuberculosis em espécimes baciloscopia negativa}

A sensibilidade do kit AMPLICOR MTB foi avaliada em 98 espécimes clínicos baciloscopia negativa (43 eram culturapositiva e 55 cultura-negativa) provenientes de pacientes ambulatoriais. A sensibilidade do AMPLICOR MTB foi de $44 \%$ (44/98) e a da cultura 43,8\% (43/98). Não foi observada diferença significativa entre os resultados dos dois métodos. Conclui-se que os ensaios de amplificação podem ser utilizados em espécimes baciloscopia negativa, porque um rápido diagnóstico beneficiará esses pacientes.

Palavras-chaves: tuberculose, AMPLICOR MTB, espécimes baciloscopia negativa.

\section{REFERENCES}

1. Brasil. Ministério da Saúde. FNS-Cenepi/Centro de Referência Professor Hélio Fraga. Boletim Epidemiológico, Ano I, n. 9, 1996
2. Cantazaro, A.; Davidson, B.L.; Fujiwara, P.I.; Goldenberg, M.J.; Gordin, F.; Salfinger, J.; Sbarbaro, N.W.; Schulger, M.F.; Sierra, M.F.; Woods, G.L. Proceeding of the American Thoracic society Workshop. "Rapid diagnostic test for tuberculosis. What is appropriate use?" Amer. J. Respir. Crit. Care, 155: 1804-1814, 1997.

3. Devallois, A.; Legrand, E.; Rastogi, N. Evaluation of Amplicor MTB test as adjunct to smears and culture for direct detection of Mycobacterium tuberculosis in the French Caribbean. J. Clin. Microbiol., 34: 1065-1068, 1996.

4. Gamboa, F.; Fernandez, G.; Padilla, E.; Manterola, J.M.; Lonca, J.; Cardona, P.J.; Matas, L.; Ausina, V. Comparative evaluation of initial and new versions of the Gen-Probe Amplified Mycobacterium Tuberculosis Direct Test for direct detection of Mycobacterium tuberculosis in respiratory and nonrespiratory specimens. J. Clin. Microbiol., 36: 684-689, 1998.

5. Ichiyama, S.; Iinuma, Y.; Tawada, Y.; Yamori, S.; Hasegawa, Y.; Shimokata, K.; Nakashima, N. Evaluation of Gen-Probe Amplified Mycobacterium tuberculosis Direct test and Roche PCR-microwell plate hybridization method (Amplicor Mycobacterium) for direct detection of mycobacteria. J. Clin. Microbiol., 34: 130-133, 1996.

6. Kent, P.T.; Kubica, G.P. Public Health Mycobacteriology. A guide for the level III Laboratory. US Department of Health and Human Services. Centers for Disease Control. Atlanta. USA. 1985.

7. Piersimoni, C.; Callegaro, A.; Nista, D.; Bornigia, S.; Conti, F.; Santini, G.; Sio, G. Comparative evaluation of two commercial amplification assays for direct detection of Mycobacterium tuberculosis complex in respiratory specimens. J. Clin. Microbiol., 35: 193-196, 1997

8. Scarparo, C.; Piccoli, P.; Rigon, A.; Ruggiero, G.; Scagnelli, M.; Piersimoni', C. Comparison of enhanced Mycobacterium tuberculosis amplified direct test with COBAS AMPLICOR Mycobacterium tuberculosis assay for direct detection of Mycobacterium tuberculosis complex in respiratory and extrapulmonary specimens. J. Clin. Microbiol., 38: 1559-1562, 2000.

9. Wang, S.X.; Tay, L. Evaluation of three nucleic acid amplification methods for direct detection of Mycobacterium tuberculosis complex in respiratory specimens. J. Clin. Microbiol., 37: 1932-1934, 1999.

10. Wobeser, W.L.; Kradjen, M.; Conly, J.; Simpson, H.; Yim, B.; D'Costa, M.; Fuksak, M.; Hian-Cheong, C.; Patterson, M.; Phillipsm, A.; Bannatyne, R.; Haddad, A.; Brunton, J.L.; Krajden, S. Evaluation of Roche Amplicor PCR assay for Mycobacterium tuberculosis. J. Clin. Microbiol., 34: 134-139, 1996. 